\title{
Devaneio e embriaguez duma rapariga de Clarice Lispector e o entrelaçamento com o mito de Narciso
}

\section{Clarice Lispector's Devaneio e embriaguez duma rapariga and its interweaving with the myth of Narcissus}

\author{
Maria da Luz Duarte Leite Silva* \\ lulinhaduarte@hotmail.com \\ Secretaria de Educação do Rio Grande do Norte \\ Francisco Igo Leite Soares ${ }^{* *}$ \\ igoleite@hotmail.com \\ Sociedade Seridoense de Educação e Cultura
}

\begin{abstract}
RESUMO: Buscamos compreender como o mito do duplo, especificamente o de Narciso se apresenta no conto Devaneio e Embriaguez duma Rapariga de Clarice Lispector, sobretudo, como o modo da atualização do referido mito se relaciona na representação da identidade dos personagens. Respaldamo-nos em alguns postulados teóricos: Rosset (2000), Jung (2008), Gotlib (1994), Cavalcanti (1992), Lowen (1983), dentre outros. Esperamos compreender como as marcas do duplo se configuram na prosa lispectoriana, observando que o espelho, no conto em questão, instiga uma forma de apropriação metafórica do mito de Narciso. Optamos por observar o modo de configuração da identidade das personagens, atentos aos indícios do mito de Narciso expressos através de metáforas como o espelho, o olhar, a maquiagem, dentre outros. Constatamos que a personagem central apresenta-se em constante busca de sua identidade.
\end{abstract}

PALAVRAS - CHAVE: Duplo. Mito. Narciso. Identidade.

ABSTRACT: We seek to understand how the myth of the double, specifically the myth of Narcissus, is present in Clarice Lispector's short story Devaneio e Embriaguez duma Rapariga, and how the actualization of the myth relates to the representation of the identity of the characters. Our discussion is based on some theoretical postulates by Rosset (2000), Jung (2008), Gotlib (1994), Cavalcanti (1992), Lowen (1983), among others. We hope to understand how the marks of 'double' are configured in Lispector's prose, noting that the mirror in the story instigates a form of metaphoric appropriation of the myth of Narcissus. We chose to observe how the identity of the characters is portrayed, attempting to find evidence of the myth of Narcissus expressed through metaphors, such as the mirror, the gaze, makeup, among others. We concluded that the central character is presented in constant search of her identity.

KEYWORDS: Double. Myth. Narcissus. Identity.

\footnotetext{
* Mestre em Letras pela Universidade do Estado do Rio Grande do Norte e doutoranda em Estudos da Linguagem pela Universidade Federal do Rio Grande do Norte

"Mestre em Engenharia de Petróleo e Gás pela Universidade Potiguar (UnP)

Odisseia, Natal, RN, v. 1, n. 2, p. 82 102, jul. dez. 2016. 


\section{Introdução}

Sabemos que o tema do duplo não é exclusivo da literatura, pois aparece em vários campos como o mitológico, o psicanalítico, o religioso, o filosófico e muitos outros. Esse tema é explorado na literatura por meio da ficção, da comédia, desde a Grécia antiga, com Aristófanes e Platão, apresentando-se através dos gêmeos, que usurpavam identidades; ou seja, o duplo é visto como um outro em si mesmo, um eu incógnito, que se reconhece por meio do processo de estranhamento. A princípio, o mito do duplo é visto como configuração do sósia ou de gêmeos, ou seja, a tendência que prevalecia era a do idêntico, da unicidade, do homogêneo. Esse mito forma-se a partir de um eu original, que detém o conhecimento da sua interioridade, para exteriorizar quem o imita, duplicando-o. É como se cada eu funcionasse como um espelho que devolve a sua imagem. É a partir de tal perspectiva que buscamos a conexão existente entre mito e literatura, procurando analisar as marcas do mito de Narciso em Devaneio e Embriaguez duma Rapariga de Clarice Lispector, sobretudo o modo da atualização do referido mito na representação das personagens. Pretendemos compreender como as marcas do duplo se configuram na prosa lispectoriana, observando que o espelho, no conto em questão, instiga uma forma de apropriação metafórica do mito de Narciso.

\section{O Mito do Duplo}

A princípio, o mito do duplo é visto como configuração do sósia ou de gêmeos, ou seja, a tendência que prevalecia era a do idêntico, da unicidade, do homogêneo. Esse mito forma-se a partir de um eu original, que detém o conhecimento da sua interioridade, para exteriorizar quem o imita, duplicando-o. É como se cada eu funcionasse como um espelho que devolve a sua imagem.

Umberto Eco (1989, p.19) apresenta o espelho em comparação a uma prótese, ou seja, um canal que possibilita o sujeito ser refletido e também ser enganado: "O espelho pode provocar engano perceptivos, como todas as próteses".

À luz de Bravo (1998, p. 45), o ser duplicado representa, também, "a loucura em oposição à sanidade, ou o dualismo entre sentimento e razão, 
consciência, imanência e transcendência, e muitos outros". A cisão, a dualidade e o outro remetem a um Eu que se apresenta como um não Eu. Conforme Lamas, (2004, p.44) "o duplo deriva da palavra de antiga tradição Alemã, Doppelganger, significando: 'aquele que caminha ao lado, companheiro de estrada, às vezes desejado, às vezes indesejado, de acordo com o sentido e a personificação expressa"'. Para essa autora, o mito do desdobramento do sujeito pode ser representado como algo idêntico e diferente, interior e exterior, podendo estar aqui e lá, ser oposto e complemento, daí ser desejado ou não. Dessa forma, esse mito revela o desdobro do sujeito, em que pode representar o encontro com o seu outro eu desprendendo-se dele.

O mito do ser duplicado é também retratado em sua origem na obra $O$ Banquete de Platão, como afirma Bravo (1998, p. 262): "O homem desdobrado, a mulher desdobrada ou o andrógeno representavam a união primitiva, o estado de perfeição a que os homens põem fim quando ameaçam os deuses"; ou seja, a princípio o homem era considerado uno e, sobretudo, perfeito, mas por transgredir os preceitos dos deuses, foi punido, sendo bipartido em masculino e feminino. A partir dessa divisão começou-se a busca desmedida pela metade perdida.

\section{Narciso e Narcisismo}

Tanto o narcisismo como o Narciso derivam da palavra grega Marke, que significa "entorpecido". Para os gregos, Narciso é a metáfora da vaidade e da insensibilidade, pois ele emocionalmente causava sofrimento àqueles e àquelas que se apaixonavam por sua beleza. Portanto, Narciso simboliza o drama da individualidade.

Na visão clássica ovidiana, Narciso enamora a si mesmo e, apaixonado por seu reflexo, encontra na morte a saída para a impossibilidade de viver esse amor. Em suma, o reflexo que é o duplo de Narciso é o objeto de seu amor. Conforme Ovídio, Narciso não tem consciência de que a imagem na água refletida lhe pertence. "Deitado no chão ele contempla duas estrelas, seus olhos; os seus cabelos, dignos de Baco, [...] a beleza de seu rosto, [...]. Sem saber, ele deseja a si mesmo" (OVÍDIO, Mit. III p. 420 - 426, apud JORDÃO, 2009, p. 69).

E como o narcisismo é característica de Narciso, citamos Freud (1997), que apresenta o narcisismo como uma fase intermediária no desenvolvimento do 
prazer entre o que denomina de autoerotismo e o amor objetal. Para ele, o distanciamento da realidade, que se dá por meio da fantasia, conserva o caráter objetal, podendo se manifestar no neurótico, naquele sujeito que, mesmo apresentando perturbação mental, é ciente de sua personalidade, não viola os princípios das normas sociais.

Na expressão de Daniel Yankelovich, citado por Lasch (1986, p. 47): "O narcisismo significa uma perda da individualidade e não a autoafirmação; referese a um eu ameaçado com a desintegração e por um sentido de vazio interior". Como se vê, o indivíduo com a evolução da sociedade voltou-se para a sua interioridade, e à medida que a sociedade se torna mais competitiva e hostil, o sujeito se distancia da coletividade.

Assim, não é o Narciso que se apaixona sem saber pela sua imagem refletida na fonte, não sendo capaz de distinguir o si mesmo, mas o Narciso que é consciente da dificuldade de conquistar a sua individuação: Assim, aquele que se vê dividido é o que nos interessa. Tal como postula Cavalcanti (1992, p.163): "Em Narciso, seu defeito é a sua perfeição, a sua desmedida, a sua onipotência, o seu estado indiferenciado e subdesenvolvido. [...] A perfeição pode representar o medo do sentimento de falta e incompletude, a vergonha de não ser perfeito".

Conforme Holmes (2002), o narcisismo advém dos espelhos, metaforizado pelo olhar da mãe. Sendo o sujeito narcísico repleto de "eus", de "mins" e de "meus", há a presença do egocentrismo, pois o sujeito demonstra pouco interesse pelo outro, tudo gira em torno de um eu, o si mesmo. Esse sujeito organiza sua vida não de modo a desenvolver uma real empatia, mas sim recursos de superfície que satisfaçam sua vaidade e possam ser empregados em seus movimentos exibicionistas.

Existem, evidentemente, outros teóricos que contribuem para o entendimento do narcisismo, como Alexander Lowen (1983), que destaca como os sujeitos não amam a si mesmos nem aos outros. Esse teórico ainda atribui os distúrbios narcísicos a problemas relacionados à infância do sujeito, desenvolvendo a negação do sentimento e ausência de limites; e considera a predominância dessa doença como proveniente da superficialidade dos valores da sociedade moderna, visto que os narcisistas apresentam várias atitudes como ambição intensa, manias de grandeza, sentimentos de inferioridade, além de excessiva dependência da admiração e aprovação externa. 
É oportuno lembrar o que nos diz Cavalcanti (1992, p. 164): "O narcisista desenvolve uma 'persona' com características perfeitas que toma o lugar do ego e leva à despersonalização". A esse processo Winnicott, baseado em Jung (2008), chama de vivência do falso Self. Ou seja, o mito de Narciso enfoca a saída do estado de indiferença com o Self, busca-se a estruturação da consciência, a constituição do eu e da identidade no processo de individuação.

Já para Holmes (2002, p. 7), o narcisismo, mais do que uma estrutura patológica, é uma forma de expressão do psíquico humano, do inconsciente do sujeito. No sentido leigo, é visto como sinônimo de egoísmo e preocupação consigo mesmo, e usado correntemente em relação a pessoas cuja fala está repleta do pronome 'eu'. Com base na ideia do autor, o sujeito narcísico é a pessoa egocêntrica, para quem o que prevalece é o seu eu, fazendo de si próprio a ponte de referência na organização de sua experiência.

Vale lembrar que, na busca incessante em ser aceito pelo outro e, ao mesmo tempo, querendo conservar a sua individualidade, o sujeito moderno acaba provocando sentimentos de angústia e vazio.

\section{Devaneio e Embriaguez duma Rapariga.}

O conto Devaneio e embriaguez duma rapariga é narrado em terceira pessoa. O narrador é onisciente, encarregando-se de contar o pensamento, os fatos, e, principalmente, o interior da rapariga, sem, contudo, desprezar a ficcionalidade. É o narrador que algumas vezes dá repostas às indagações da protagonista. "Ai que cousa que se me dá! minha santa mãe! Pensou desesperada. Teria comido demais?" (LISPECTOR, 1998, p. 18). Responde o narrador: "É a tristeza." A sequência dessa narrativa é não linear, o tempo é visto por acontecimentos presentes já ocorridos, por meio das lembranças, prevalecendo o tempo psicológico.

Todo o discurso nesse texto está no fluxo de consciência da personagem, pois o conflito da narração só existe nesse espaço dissimulado. $O$ espaço físico da narrativa resume-se no quarto da portuguesa e no restaurante em que a protagonista vai jantar juntamente com seu marido e com um comerciante abastado. Nesse conto, a figura feminina é apresentada como um sujeito descentrado. A personagem mostra-se entediada com seu papel de esposa e mãe 
de família, chegando a relaxar em suas tarefas; por ficar presa à cama, o marido pensa que a sua senhora está adoentada.

Devaneio e embriaguez duma rapariga conta a história de uma portuguesa que se encontra, como várias mulheres, presa ao cotidiano da casa, vivendo confinada em seus afazeres domésticos. Antes de sentir-se desligada da vida, tinha várias obrigações diárias, agora nada lhe preocupava, até mesmo o lavar as roupas, o "cezir as peúbas". Ao devanear e lembrar das suas tarefas cotidianas, reflete sobre isso e percebe o seu estado atual como saída para uma nova vida, daí diz: "[..] ai que vagabunda que me saíste!" (LISPECTOR, 1998, p. 12). A protagonista demora a perceber que a vida que levava não era significativa, ou melhor, não Ihe trazia felicidade. O seu esposo, ao se aproximar dela para acariciála faz a mesma refletir sobre se está ou não doente. Essa mulher despreza filhos, marido e casa, mas, ao descobrir que era importante, mesmo sendo uma senhora dona de casa, resolve ser ela mesma e não outra.

A protagonista do conto Devaneio e embriaguez duma rapariga é de uma família de origem Portuguesa de classe média. O narrador procura apresentar expressões típicas lusitanas; isso é percebido através da linguagem das personagens, que usam expressões próprias da cultura e o jeito de falar de Portugal, conforme se observa a seguir: "Bons dias, sabes quem veio a me procurar cá à casa?"; "Haveria certas cousas boas porque era quase nauseantes" (LISPECTOR, 1998, p. 10). No próprio título do conto, é possível observar a marca do lusitanismo no uso do termo "rapariga," que em Portugal indica mulher jovem - a moça. Este conto inicia com o narrador apresentando ao leitor o cenário em que se passa toda a história; nesse caso, grande parte do enredo se dá no quarto da personagem. Mas é mostrado também o cenário de origem dessa mulher, pois a portuguesa desloca-se da sua cidade natal - Portugal - para morar no Brasil, especificamente no Rio de Janeiro, na rua Riachuelo.

Percebemos, também, que a sequência da história não ocorre linearmente; a narração transita entre um tempo presente e acontecimentos já ocorridos, o que se observa por meio da introspecção psicológica da protagonista. "Mas finalmente a dificuldade de chegar em casa desapareceu: remexia-se agora dentro da realidade familiar de seu quarto, agora sentada na borda de sua cama com a chinela a se balançar no pé" (LISPECTOR, 1998, p. 15-16). 
Esse fragmento leva-nos a entender que a protagonista, por meio da introspecção psicológica, inicia a procura da sua identidade. Isso é possível ser percebido, porque o narrador não se preocupa com as sequências dos fatos, nem mesmo com a sequência cronológica, uma vez que o que interessa é a repercussão das ações em si. De acordo com Silva (2007, p. 48), em Clarice "O centro de suas narrativas é ocupado não por aventuras extraordinárias, por peripécias, mas pelos pensamentos e pela angústia das personagens - pela repercussão dos fatos [...]".

Por isso, quando se diz que a personagem encontra-se em processo de introspecção psicológica, faz-se transparecer mais uma evidência do que mencionamos, ou seja, é a ação que apresenta significado na construção do sentido da narrativa lispectoriana.

\section{O Esfacelamento da protagonista no conto Devaneio e Embriaguês duma Rapariga}

O conto Devaneio e embriaguez duma rapariga é a história de uma personagem que não apresenta nome, é uma mulher que procura refugiar-se por trás de máscaras como o álcool, o espelho, o outro, o olhar e muitas outras, como forma de superar a rotina de sua vida.

Nesse conto, logo no início, percebemos a vontade da portuguesa em conhecer-se, ou individuar-se, e viu-se como uma rapariga ainda jovem: "Teve a visão de seu sorriso claro de rapariga ainda nova, e sorriu mais fechando os olhos, a abanar-se mais profundamente. Ai, ai, vinha da rua como uma borboleta" (LISPECTOR, 1998, p. 10). Essa ideia nos remete as palavras de Jung (2008), quando reflete a respeito da individuação do sujeito, e seu despojamento dos laços da persona. Isso é percebido na protagonista do conto em questão, visto que a portuguesa reflete sobre o seu eu. A borboleta é mais uma simbologia que a autora utiliza para se compreender o eu da protagonista, nos leva a pensar que a rua possibilita ao sujeito ter liberdade, e essa liberdade, no conto, é metaforizada pela borboleta, uma vez que esta pode simbolizar a libertação da alma e a transformação da mulher - a protagonista - que ocorre por meio de seus devaneios, pois se deixa levar por fantasias, lembranças, sonhos, sendo dominada por esse estado de espírito.

Esse conto, na opinião de Nádia Gotlib (1994, p. 322), é "o mais humorado Odisseia, Natal, RN, v. 1, n. 2, p. 82 102, jul. dez. 2016. 
de toda ficção de Lispector". Nele é patente o devaneio da portuguesa que, morando no Brasil, consegue como tantas outras personagens de Lispector, através de acontecimentos aparentemente banais, e por meio da tão famosa introspecção psicológica, escapar da rotina. Envolta nesse escapismo a personagem indaga sobre "Quem sou eu?" Isso ocorre, nesse conto, pelo processo metafórico como o olhar reflexivo sobre si e o outro, além da embriaguez da protagonista.

Vemos o olhar da "mulher" no espelho como uma representação do seu esfacelamento, pois o espelho é constituído de três pedaços, nos remetendo à ideia de reflexo e reflexão, e podendo também proporcionar a fragmentação de quem nele se projeta. Essa divisão do espelho em três faz-nos ver que a portuguesa estava descentrada, despedaçada, o que provocou a crise em sua identidade, pois a imagem pode representar o que ela é e como deseja ser, ou seja, o eu possível e o que a sociedade projeta para ela. Assim sendo, a personagem pode se ver de três maneiras diferentes ou não se reconhecer. Olharse ao espelho pode ser visto também como uma maneira de encontrar-se ou reencontrar-se, seja como o duplo em que o indivíduo projeta e concentra as imagens que faz de si próprio, ou simplesmente vendo sua imagem refletida. "Os olhos não se despregavam da imagem, o pente trabalhava meditativo, o roupão aberto deixava aparecerem nos espelhos os seios entrecortados de várias raparigas" (LISPECTOR, 1998, p. 09). Este trecho nos permite perceber a dualidade da protagonista, ou o seu drama. Conforme afirma Rosset (2000, p. 90), "O espelho não mostra o eu, mas o inverso, um outro; não meu corpo, mas uma superfície, um reflexo". Esta fala nos remete ainda à ideia de que o espelho é um meio que possibilita o descentramento do sujeito, e é isso que ocorre com a rapariga do conto em questão. Assim, a presença do espelho serve como metáfora do ver-se e do reflexo sobre o eu e o outro, servindo, sobretudo, como uma forma de apropriação metafórica do mito de Narciso. Podemos dizer que, no decorrer da narrativa, o espelho e a embriaguez serviram para a portuguesa refletir sobre a sua constituição como sujeito. É tanto que essa senhora se vê duplicada entre dois papéis, ora vista como uma dona de casa numa vida rotineira, ora vista como uma mulher à espera de uma nova vida. "Acordou com o dia atrasado, as batatas por descascar, os miúdos que voltariam à tarde das titias, ai que até me faltei ao respeito. [...] Quando o amigo do marido a Odisseia, Natal, RN, v. 1, n. 2, p. 82 102, jul. dez. 2016. 
viu tão bonita e gorda ficou logo com respeito por ela" (LISPECTOR, 1998. p.18).

Nesse jogo de duplos, podemos relacionar a constituição da protagonista do conto Devaneio e embriaguez duma rapariga com o mito de Narciso, pois ambos trazem a metáfora do espelho. Entendemos que o olhar-se em Narciso está relacionado à busca da identidade relativa ao ego, ao impulso, para a diferenciação do eu em relação ao não eu. Além disso, vale lembrar que, nesse conto, o duplo se apresenta por meio de diversos tipos de relações, nas quais a duplicidade é proporcionada pelo outro, este configurando-se através da loira e do eu exterior da personagem, ou seja, o outro serve de inquietação à portuguesa na construção da imagem de si. Atrasada para a tarefa de descascar batatas a protagonista deixa transparecer uma de suas atividades rotineiras. Já o olhar do negociante próspero, a deixa lisonjeada e com esperança de uma vida diferente; antes desse jantar a portuguesa vivia em um mundo restrito ao lar e aos cuidados de uma dona de casa. A partir dessa saída de casa, essa mulher encontra-se como um ser que não se conhece, isso é visto no refletir sobre as suas ações ou comportamentos como nesse trecho: "Ai que esquisita estava" (LISPECTOR, 1998, p. 13).

Outro fato interessante é quando "a mulher" vê outra mulher no restaurante, uma loira magra, com pouco busto. O que inquietava a portuguesa é o fato de essa mulher estar de chapéu e, para a protagonista não estar usando esse acessório a deixava desnudada: "Seus olhos de novo fitaram aquela rapariga que, já d'entrada, Ihe fizera subir a mostarda ao nariz. [...]. Oh, como estava humilhada por ter vindo á tasca sem chapéu, a cabeça agora parecia-lhe nua” (LISPECTOR, 1998, p. 15).

Neste momento a personagem se sente ameaçada e começa um dos seus devaneios, pois começa a pensar se aquela moça seria vista como sendo mais importante do que ela. Nesse caso, a protagonista fica a refletir sobre o seu corpo e o daquela figura feminina que a perturbava. A sua contemplação se dá relacionada à diferença em relação àquela loira, uma vez que compara o seu físico de mulher casada a um outro, que não sabia de certo quem era. Isso é perceptível nessa fala: "E a outra com seus ares de senhora, a fingir de delicada" (LISPECTOR, 1998, p. 15). Vemos também que aquela é o elemento que propicia à protagonista o refletir sobre a sua individualidade, visto que, mesmo tendo sido admirada pelo amigo, a "mulher" fixa-se em detalhes da outra. À luz do pensamento de Adorno (1985, p. 24) por meio de seu conceito de esclarecimento, a loira funciona para a portuguesa como o signo do esclarecimento: "Os homens recebem o seu eu como algo Odisseia, Natal, RN, v. 1, n. 2, p. 82 102, jul. dez. 2016. 
pertencente a cada um, diferente de todos os outros".

Vale salientar que a comparação do corpo da portuguesa com o da loira pode estar relacionada à questão da constituição do si mesma; a mulher, pelo caráter da diferença, constitui-se como um reflexo e, assim, é pelo signo da divergência que a portuguesa toma conta do não eu. Nesse caso, é através do outro que a portuguesa é capaz de saber quem é aquela diferente dela. Isso é representado pelo narrador: "E vai ver que, com todos os seus chapéus, não passa duma vendeira d'hortaliça a se passar por grande dama" (LISPECTOR, 1998, p. 15). O julgamento do outro, também é patente nesse fragmento, pois a portuguesa julga a mulher pela aparência "loira como um escudo falso, toda santarrona e fina" (LISPECTOR, 1998, p. 15). Essa fala da protagonista sugere certo sentimento de inveja, o que revela uma característica do narcisismo. O sujeito narcisista não apresenta apenas uma condição patológica, mas também constrói um protetor do psiquismo, ou melhor, uma imagem de si unificada e perfeita.

Na narrativa, percebemos que a protagonista pensa que essa moça não é capaz de parir. Mesmo pensando assim, a portuguesa via na loira um reflexo, ainda que diferente do seu, o que possibilita o refletir sobre o seu eu, uma das principais características do mito de Narciso

A figura do negociante próspero, amigo, do esposo da portuguesa, também serve para fazê-la refletir sobre a sua individualidade, visto que a conversa com esse negociante conquista sua atenção, pois a personagem sentiu-se importante, e, em devaneio, concluiu que tudo valeria à pena; é como se passasse no seu pensamento que ela era uma pessoa especial. Isso se confirma neste trecho: "Ouvia intrigada e deslumbrada o que ela mesma estava a responder: - já agora ela não era uma lagosta, era um duro signo: escorpião" (LISPECTOR, 1998, p. 14). Essa ideia a transformou, pois, a partir desse momento, ela se tornou uma pessoa decidida, poderosa e apaixonada. É tanto que, ao chegar a sua casa, resolve dar um esfregaço na sujeira, e, sobretudo, retomar a sua vida. A embriaguez da protagonista faz emergir a vontade de conhecer-se a si mesma; e, ao comunicarse com o negociante com certa espontaneidade por conta do álcool, apresenta certo sentimento de grandeza. Fala com espontaneidade, "Pois palestrava naturalmente. Pois que não Ihe faltava assunto nem capacidades" (LISPECTOR, 1998, p. 13).

O olhar ao espelho por sua natureza dual desencadeou a duplicidade da Odisseia, Natal, RN, v. 1, n. 2, p. 82 102, jul. dez. 2016. 
protagonista, visto que se sentia dividida em três reflexos que emblematizam a cisão do eu. Assim a personagem por uns momentos reflete sobre o seu "eu", provocada pelo álcool e por sua condição de vida; e isso nos possibilita fazermos a analogia com o mito de Narciso, visto que o devaneio provocado pelo olhar decorre do reflexo no espelho, bem como da imagem do outro e do próprio desassossego inerente ao estado de depressão da personagem. Daí a constituição e semelhança da portuguesa com Narciso. Essa ideia encontra pertinência na visão de Cavalcanti (1992, p. 205): "No episódio do espelho, estamos novamente diante da questão da construção da identidade da formação do eu". O narrador reforça essa ideia, ao afirmar: "Ouvia intrigada e deslumbrada o que ela mesma estava a responder: que dissesse nesse estado valeria para o futuro em augúrio - já agora ela não era lagosta, era duro signo: escorpião, pois [...] nascera em novembro" (LISPECTOR, 1998, p. 14).

É nesse momento que a personagem descobre que, por traz do eu cotidiano, existe um outro, o não eu; é como se ela possuísse dois eus sendo que a sua duplicidade estava atrelada a um sujeito possível. A busca desse novo ser ocorre sugestivamente através da fuga do real, ocasionada pela embriaguez, vista pela protagonista como única forma de suportar a sua vida rotineira. Depois da experiência com o álcool, a portuguesa descobre que não é mais a mesma, essa mulher deixa de ser uma lagosta para se transformar num escorpião. Ao ver-se intrigada e deslumbrada sobre o que ela mesma estava a pensar, a personagem está diante do processo de introspecção psicológica, refletindo, pois, sobre o seu verdadeiro ser. É nesse cenário propício às reflexões que a portuguesa deixa de ser, momentaneamente, uma mulher atrelada à vida simples, para tornar-se a mulher possível que, representa força, coragem e iniciativa, cuja senhora só se apresenta, quando usando algum tipo de mascaramento. Torna-se oportuno lembrar o que assinala Sant'Anna, citado por Hohfeld (1998), sobre as personagens de Lispector: "Percepção de uma realidade atordoante quando os objetos mais simples, os gestos mais banais e as situações cotidianas comportam iluminação súbita na consciência dos figurantes." É o que acontece com a portuguesa que, a partir de um simples olhar-se ao espelho, inicia um processo de autoconhecimento.

É bom lembrar que nem sempre a portuguesa sentia-se decidida a viver a maior parte do tempo deitada em seu quarto, desligada de tudo e de todos, fato raro na vida da mulher: "E, já que os filhos estavam na quinta das titias em Odisseia, Natal, RN, v. 1, n. 2, p. 82 102, jul. dez. 2016. 
Jaquarepaguá, ela aproveitou para amanhecer esquisita: túrbida e leve na cama, um desses caprichos, sabe-se lá" (LISPECTOR, 1998, p. 10). Ainda refletindo sobre o retorno dos filhos, observamos que a portuguesa sente-se um pouco entediada, começando mais um dos seus devaneios. O mal tomava conta da personagem, de modo que essa não fazia mais nada; e isso lhe causa sofrimento emocional e, consequentemente, existencial. Tal característica nos faz lembrar os postulados de Lowen (1983, p. 9), quando apresenta que: "Em nível cultural o narcisista pode ser considerado como perda de valores humanos - uma ausência de interesse pelo meio ambiente, pela qualidade de vida, pelos seus semelhantes". Isso tudo é o que acontece com a portuguesa, visto que ela preferia ficar o dia inteiro na cama, no silêncio da casa sem a presença das crianças, sem o marido, enfim sozinha. O dia para essa senhora durava uma eternidade. "A manhã tornouse uma longa tarde inflada que se tornou noite sem fundo amanhecendo inocente pela casa toda" (LISPECTOR, 1998, p. 11). Aqui também observamos o quanto a vida rotineira dessa senhora contribuiu para a sua depressão. Fazia todos os dias a mesma coisa, sem contar que vivia confinada em seu quarto. "Na cama a pensar, a pensar, quase a rir como a uma bisbilhotice. A pensar. O que? Ora, lá ela sabia. Assim deixou-se a ficar". Quando a personagem ficava a rodar de um lado para outro no quarto, desnorteada pensando que podia estar doente é mais um indício de seu descentramento.

Entendemos que o álcool pode ser entendido, nessa narrativa, como "embriaguez narcótica" de que fala Adorno (2008), em que o sujeito embriagado expia com sono parecido à noite a euforia na qual o indivíduo se sente suspenso; uma tentativa do eu fugir dos seus tormentos, por isso a personagem despreza o carinho do esposo e os afazeres domésticos "- Larga-te daí! - E o que tens? Pergunta-lhe o homem atônito, a ensaiar imediatamente carinho mais eficaz" (LISPECTOR, 1998, p. 11). Essa cena sugere o momento de isolamento por qual passava aquela senhora, pois nada motivava o seu interesse pela vida. Outro indício desse retraimento pode ser identificado no ato de guardar o próximo pensamento, mantendo-se em sua ociosidade, deitada no quarto até adormecer de boca aberta, com a baba a escorrer no canto de sua boca, mais uma característica de quem não está normal. Sem contar que ela não se incomodava com os afazeres domésticos e os cuidados com o marido. Mesmo consciente da sua limitação diante da vida, expressava constantemente a vontade de constituir-se como um sujeito Odisseia, Natal, RN, v. 1, n. 2, p. 82 102, jul. dez. 2016. 
diferente, que não fosse uma pessoa presa ao universo da casa. A expressão "[...] a manhã pressurosa do sol" (LISPECTOR, 1998, p. 12). Permite perceber que suas atividades diárias eram coisas que deveriam ser executadas. Vale lembrar que foi a partir da ida da portuguesa ao pasto que essa mulher começou a refletir sobre o seu eu.

No retorno para casa, após o jantar, continua o processo introspectivo da personagem sobre si mesma; ela sente estar voltando ao seu tamanho normal, condição de mulher que cuidava de filhos, esposo e casa. "[...] quando ela voltasse ao seu tamanho comum, o corpo anestesiado estaria a acordar latejando e ela iria pagar pelas comilanças e vinhos" (LISPECTOR, 1998, p. 16). A protagonista, em seu devaneio provocado pela embriaguez, sentia-se cheia de palavras, parecia que era outra mulher. Conforme já afirmado por Lowen (1983), os sujeitos narcísicos apresentam sentimentos intensos de fantasias, de grandeza, de inferioridade, de admiração de aprovação externa. Essa ideia nos leva a refletir sobre o mascaramento do sujeito moderno, especificamente o da protagonista desse conto, uma vez que entendemos a sua embriaguez como uma espécie de escapismo.

Toda a narrativa é perpassada por devaneios da protagonista, inclusive no momento em que ela ouve o estremecer do "guarda-louça" na sua sala, e aguarda seu próximo pensamento. São esses e outros fatos do conto que comprovam a fuga da portuguesa, justamente com o estado de sua embriaguez. Dito de outro modo, as personagens lispectorianas quase sempre deslocam-se no espaço, estando também submetidas à introspecção dos pensamentos. Há sempre um momento em que elas tentam escapar de sua vida rotineira, de seus papéis, deixando emergir um outro ser.

Vale lembrar que o espelho pode admitir múltiplos significados simbólicos. Conforme o dicionário de símbolos, de Chevalier \& Gheerbrant (1992), podem ser vistos como instrumentos de autocontemplação e reflexão do eu, do outro e do universo; ligados ao mito de Narciso, podem representar a consciência humana, simbolizando o pensamento em si mesmo. Os espelhos também podem ser símbolos de pureza e sinceridade, ao se apresentarem límpidos; bem como podem trazer significados pejorativos, como a vaidade.

Segundo Eco (1989, p.13): "No momento em que se delineia a 'virada' do eu especular para o eu social, o espelho é a 'encruzilhada estrutural' ou, como 
dizíamos, fenômeno-limiar". Assim, vemos que o espelho pode ou não ajudar o sujeito a encontrar-se consigo mesmo.

Observamos que, ao desenvolver seu pensamento interior, a personagem pensa por alguns momentos que não é mais ela mesma, ou melhor, a mulher, acomodada com a vidinha de dona de casa, passa a ser um outro ser. Essa retrospecção de personalidade é destacada em: "Gritou-lhe o mundo. Mas ela nem sequer respondeu-lhe, a alçar os ombros com um muxuxo amuado, importunada, [...] desiludida, resignada, empanturrada, casada, contente, a vaga náusea" (LISPECTOR, 1998, p.17).

Podemos dizer que, ao sentir-se empanturrada, casada, contente e com náusea, a portuguesa mostra-se procurar a resposta do "Quem sou eu?" A sua inquietação é mais uma prova do seu esfacelamento. Isso acontece em várias passagens do conto, inclusive quando ela começa a se refletir no outro, na loira, despertando um ato contemplativo. Reportando a Adorno e Horkheimer (1985, p. 22), percebemos que a portuguesa só pode alcançar o seu eu: "Enquanto tal imagem e semelhança que o homem alcança a identidade do eu que não pode se perder na identificação com o outro, mas toma definitivamente posse de si mesma como máscara impenetrável".

Assim, a personagem precisa identificar-se com um eu diferente do outro para constituir-se. Sem dúvida, estudiosos do narcisismo moderno já destacavam que a sociedade moderna conforme afirma Baumam (2005) pode causar o descentramento do indivíduo.

Nesse conto, percebemos nitidamente o quanto a portuguesa valoriza 0 status, e este é buscado por meio do outro, seja real, seja como forma de reflexo. Todo processo reflexivo da portuguesa ocasiona a crise de identidade da protagonista, percebemos isso no deslocamento da sua estabilidade interior, pois se arrumou toda para o jantar, comprovando que ela também, enquanto sujeito moderno está preocupado com sua imagem. Daí, observamos, no modo de representação da protagonista, marcas ideológicas típicas da modernidade, visto que: "[...] ela com vestidito novo que não se não era cheio d'enfeites era de bom pano superior, desses que Ihes ia durar a vida afora" (LISPECTOR, 1998, p. 12). Quando se refere a pano superior lembra-nos a representação que é dada à portuguesa, uma mulher de classe média que morava em capital, por isso conhece 
o que é bom e sofisticado.

Assim como o Narciso moderno é consciente de sua dualidade, a portuguesa, na qualidade de ser ficcional inserido no contexto moderno, também se coloca como sujeito que sabe de sua condição de ser cindido; o que pode ser conferido no trecho que segue: "E ela cada vez maior, vacilante, túmida, gigantesca. Se conseguisse mais perto de si mesma, ver-se-ia inda maior" (LISPECTOR, 1998, p. 16). A personagem se encontra como Narciso desdobrada em processo de transformação, pois dialoga consigo mesma e com o outro para individualizar-se, do eu e do não eu. Percebemos o egocentrismo da portuguesa quando está diante do homem próspero e do marido; o que podemos confirmar, quando o narrador diz: "E se quisesse podia permitir-se o luxo de se tornar ainda mais sensível, ainda ir mais adiante: porque era protegida por uma situação, protegida como toda gente que atingiu uma posição na vida" (LISPECTOR, 1998, p. 14).

Ainda, em se tratando dessa proteção, vemos como a protagonista se sente regozijada no restaurante quando há duas pessoas que, aos olhos da personagem, são seus protetores. Por isso, ao sentir-se protegida pelo comerciante próspero e pelo marido, imaginava ser outra. $\mathrm{O}$ jantar com uma pessoa importante causava-lhe deslumbramento, dando espaço para os seus devaneios, como em: "A patifas sem brio como tu, a se fazerem de rogadas, eu lhas encho de sopapos" (LISPECTOR, 1998, p.15).

Todo esse conto é entrecortado pelo devaneio da portuguesa, possibilitando o refletir sobre o si mesma. E, como forma de romper com o paradigma social sobre os papéis exercidos pela mulher, a mulher-mãe e dona de casa que decide mudar de comportamento: "Que preguiçosa e relaxada que me saíste. Amanhã não, porque não estaria lá muito bem das pernas. Mas depois de amanhã aquela casa haveria de ver" (LISPECTOR, 1998, p. 18). Nesse momento, a personagem apresenta-se como uma mulher preguiçosa e relaxada. Ela se vê, tomando as palavras de Lasch (1986), como um eu mínimo. Esse autor, ao referir-se ao narcisismo de hoje como uma prática de sobrevivência psíquica do homem, utiliza a expressão eu mínimo. A fala do narrador a seguir esclarece esse processo, em que a protagonista apresenta interiorizando o seu eu: "Tudo, no fundo, estava igual, só que menor e familiar. Estava sentada bem tesa na cama, o estômago tão cheio, 
absorta, resignada, com delicadeza de quem esperava sentado que o outro acorde".

Será que esse outro que a personagem esperava acordar não é o seu duplo? Será que, nesse momento, se entrelaçava, no pensamento dessa mulher, o que seria a sua vida real e a sua vida possível? Sugestivamente, acreditamos que o duplo da portuguesa se configura no instante em que se vê bipartida, como no momento em que se via refletida no espelho, em várias raparigas, bem como quando se projetava na loira no restaurante. Esses são alguns exemplos que nos possibilita perceber o embaraçamento entre vida real e a projeção/imaginação.

A protagonista do conto Devaneio e embriaguez duma rapariga, ao encontrar-se momentaneamente consigo mesma, percebe que também tem o seu valor, como podemos confirmar nessa fala: "Ai que se sentia tão bem, tão áspera, como se ainda estivesse a ter leite nas mamas, tão forte" (LISPECTOR, 1998, p. 18). Esse fato mostra ainda mais a semelhança dessa narrativa com o mito de Narciso, pois este, ao perceber que amava a si mesmo continuou a admirar-se, ocasionando o seu definhamento. Segundo Cavalcanti (1992, p. 208): "Narciso brinca com a imagem de si mesmo no outro e do outro em si mesmo, buscando a sua identidade, sua condição de ser no mundo".

Se pararmos para pensar na presença da busca da constituição do si mesmo nesse conto, veremos indícios no próprio título, quando, por exemplo, se devaneia estar um tanto fora do real, sonhando, fantasiando, imaginando, delirando, desvairando-se, devaneando, meditando, pensando vagamente em coisas e acontecimentos, dizendo coisas sem nexo, absorvendo-se em vagas meditações. $E$ embriaguez se refere ao estado em que o sujeito apresenta-se entusiasmado, com êxtase; o que acontece em várias passagens dessa narrativa, como por exemplo: "[...] e ela com os cotovelos sobre a toalha de xadrez vermelho-e-branco da mesa sobre o jogo, profundamente lançada numa vida baixa e revolucionante" (LISPECTOR, 1998, p. 13).

Percebemos, nesse fragmento, que o devaneio era uma saída para essa senhora, pois, quando diz que é bom perder a alma diária, confirma esse fato. Ainda recorrendo à fala da protagonista, o narrador procura mostrar que, por meio da expressão “mãos pequenas e maltratadas" (LISPECTOR, 1998, p. 13). Essa mulher pode ser uma pessoa delicada por apresentar mãos pequenas e ao mesmo tempo um sujeito de vida dura por ter as mãos maltratadas. Isso nos remete à ideia Odisseia, Natal, RN, v. 1, n. 2, p. 82 102, jul. dez. 2016. 
de que sua vida era de dona de casa responsável por todos os afazeres domésticos; daí o estrago das mãos.

Outro momento importante é quando se refere à toalha de xadrez, levandonos a entender que esta pode ser uma metáfora da vida da protagonista, que é comparada a um jogo, e esse jogo pode ser entendido pelo narrador como a busca da identidade. O próprio fato da personagem não ter um nome representa que a mulher é esvaziada de sua identidade.

Vale lembrar que o narrador apresenta a personagem da história como a portuguesa ou a mulher, e que traços definidores dessa senhora são sugeridos por meio da sua interioridade, do psicologismo e de suas ações cotidianas. Assim, é por meio dos devaneios, ocasionados pela embriaguez, da conversa, e de seus questionamentos, bem como da vontade de ser um eu possível que a protagonista se questiona diante do espelho e de outros reflexos.

Toda a narrativa em questão é repleta de momentos de delírios. O dicionário online Dicio (2016) atribui a essa palavra a acepção: "estado mórbido que leva o paciente a proferir palavras sem nexo, exaltação, e entusiasmo, perturbação intelectual, produzida por doença e excesso de sentimento".

Quando o marido chega em casa e ela o rejeita é porque quer se distanciar dele e da vida cotidiana. Percebemos que no quarto ela pode dedicar-se ao processo de autoconhecimento. "Ai que quarto suculento! Ela se abanava no Brasil" (LISPECTOR, 1998, p. 18). Por não Ihe dar muita importância, o esposo suspeita que sua esposa esteja doente, pois continua a devanear, pensando no jantar a que fora com o marido e o negociante abastado. "Que desprezo pelas pessoas secas do restaurante, [...]. E tudo no restaurante tão distante um do outro como se jamais um pudesse falar com o outro. Cada um por si, e lá Deus por toda a gente" (LISPECTOR, 1998, p.14).

É nesse jantar que a duplicidade de sua vida como esposa e como mulher é revelada, no momento em que reflete interiormente por estar sendo galanteada pelo patrão do marido, bem como no momento em que desenvolve inveja pela moça loira, apresentada pelo narrador como de peitos chatos, cintura fina e usando chapéu.

Quando a protagonista demonstra que a loira, apesar de mostrar-se com alguns padrões de beleza eleitos pela sociedade, talvez não fosse casada, remete- 
nos à ideia de que a personagem via no casamento uma forma de aquisição de respeito. Mesmo assim, pensa em encher a loira de pancadas. "A patifas sem brio como tu, a se fazerem de rogadas, eu lhas encho de sopapos" (LISPECTOR, 1998, p.15). Apesar de apresentar essa vontade de ser melhor do que a outra, a loira, ela indaga sobre si mesma, pensando que não passava de uma dona de casa com seus afazeres domésticos. Isso se confirma no trecho a seguir: "Se conseguisse chegar mais perto de si mesma, ver-se-ia inda menor" (LISPECTOR, 1998, p.16). Observamos que a protagonista apresenta medo de encontrar-se com o verdadeiro eu. Ao conseguir individualizar-se a personagem descobre que sua vida é rotineira, daí encontra no mascaramento a única solução de fuga.

Um outro momento na narrativa em que percebemos o descentramento da protagonista é na hora em que fica surda e mete um tapão em seu rosto. Nesse instante, ela sente uma "sensação maliciosa e incômoda" (LISPECTOR, 1998, p.17) e suspira, apresentando uma saciação conformada: "Pros raios que os partam, disse suave, e aniquilada" (LISPECTOR, 1998, p.17). Outros elementos no conto que são importantes para percebermos a vontade de mudança de identidade da portuguesa são o sabão e a água que simbolizam a censura, a compostura e a repreensão; e servem também, no conto, como metáfora que pode representar uma maneira de limpar aquela vida monótona, rotineira, ou seja, representa o lavar algo sujo. Sugestivamente a sujeira aqui pode significar o descaso consigo mesma e com os outros. Vejamos, a seguir: "Mas depois de amanhã aquela sua casa havia de ver: dar-Ihe-ia um esfregaço com água e sabão que se lhe arrancariam as sujidades todas" (LISPECTOR, 1998, p.18). É no devaneio provocado pela náusea que a protagonista encontra o si mesma: é esposa, tem filhos, tem tarefas domésticas a realizar; e, como forma de rever suas ações, a protagonista resolve arrumar sua casa. A busca de sua identidade ocorre de modo tortuoso, de modo que no final do conto a protagonista se compara a uma cadela. "Então a grosseira explodiu-lhe em súbito amor: cadela, disse a rir" (LISPECTOR, 1998, p.18).

\section{Algumas Considerações}

Na leitura empreendida do conto Devaneio e Embriaguez duma Rapariga, de Clarice Lispector, optamos por observar o modo de configuração da identidade das personagens atentos aos indícios do mito de Narciso expressos através de 
metáforas como o espelho, o olhar, dentre outros. Nessa análise, constatamos que a personagem central apresenta-se em constante busca de sua identidade.

Observando o modo de configuração da arquitetura ficcional de Clarice Lispector, sobretudo, o modo de representação da personagem, pudemos perceber que a construção da identidade ocupa espaço privilegiado nessa narrativa. Nesse conto, a protagonista configura-se como sujeito descentrado. Verificamos que uma das características da contística lispectoriana é o drama das personagens em entender o "Quem sou eu?" Essa pergunta acaba desencadeando em suas protagonistas uma cegueira narcísica, uma cegueira que é o signo de sua alienação em relação a si mesmo, e, aos seus mundos.

No conto elencado, o descentramento da personagem é patente. $\mathrm{Na}$ portuguesa, isso acontece ao projetar o seu reflexo no espelho, e diante do outro e do álcool. Dessa forma, a problemática do mito de Narciso é atualizada na representação da personagem do conto estudado, visto que o descentramento ocasionado pelos vários reflexos remonta um problema que é de Narciso e também das figuras femininas de Clarice Lispector.

Percebemos que na literatura, o mito adquire um sentido novo por meio de metáforas expressas em diferentes situações narrativas. E constatamos que, na narrativa analisada, o duplo configura-se de forma heterogênea, uma vez que a personagem, quando se olha no espelho, enxerga-se como um eu esfacelado; a portuguesa, ao ser refletida no espelho de três ângulos, torna-se consciente de desdobramento do eu.

\section{Referências}

ADORNO, T. W; HORKHEIMER, M. Dialética do esclarecimento: fragmentos filosóficos. Trad. Guido Antonio de Almeida. Rio de janeiro: Zahar, 1985.

Mínima moralia: Reflexões a partir da vida lesada. Rio de Janeiro: Beco do Azougue, 2008.

BAUMAN, Z. Identidade: entrevista a Benedetto Vecchi. Trad. de Carlos Alberto Medeiros. Rio de Janeiro: Jorge Zahar. Ed, 2005.

BRAVO, N. F. Duplo. In: BRUNEL, P. (Org.). Dicionários de mitos literários. 2.ed. Rio de Janeiro: José Olympio, 1998. p. 261- 288. 
CAVALCANTI, R. O mito de narciso: o herói da consciência. São Paulo: Cultrix, 1992.

CHEVALIER, J. GHEERBRANT, A. Dicionário de Símbolos: mitos, sonhos, costumes, gestos, formas, figuras, cores, números. 6.ed. Rio de Janeiro: José Olympio, 1992.

DELÍRIO. In: Dicio: DICIONÁRIO online de português, 2016. Disponível em: <https://www.dicio.com.br/delirio/>. Acesso em: 01 jul. 2016.

ECO. U. Sobre os espelhos e outros ensaios. Trad. de Beatriz Borges. Rio de Janeiro: Nova Fronteira, 1989.

FREUD, S. O estranho. Rio de Janeiro: Imago, 1997. p. 237-265.

. Sobre o Narcisismo: Uma introdução. Rio de Janeiro: Imago, 1997.

HOHLFELD, A C. Conto brasileiro contemporâneo. 2.ed. Porto Alegre: Mercado Aberto, 1998.

HOLMES, J. Narcisismo. Coimbra: Almedina, 2002.

GOTLIB, N. B. Os difíceis Laços de Família. Cadernos de Pesquisa, São Paulo, n. 91, p. 93-99, nov. 1994. Disponível em: <http://publicacoes.fcc.org.br/ojs/index.php/ cp/article/view/881/887>. Acesso em: 01 jul. 2016.

JORDÃO, A. A. Narcisismo: do ressentimento à certeza de si. Curitiba: Juruã, 2009.

JUNG, C. G. Os arquétipos e o inconsciente coletivo. Petrópolis: Vozes, 2008.

. Os arquétipos e o inconsciente coletivo. Petrópolis: Vozes, 2000.

LAMAS, B. S. O Duplo em Lygia Fagundes Telles: um estudo em psicologia e literatura. Porto Alegre: EDIPUS, 2004.

LASCH. C. O mínimo Eu: sobrevivência psíquica em tempos difíceis. 4.ed. São Paulo: Editora Brasiliense, 1986.

A cultura do Narcisismo. Rio de Janeiro: Imago, 1983.

LISPECTOR, C. Laços de Família. 2.ed. Rio de Janeiro: Rocco, 1998.

LOWEN, A. Narcisismo: negação do verdadeiro Self. São Paulo: Cultrix, 1983.

OVIDIO, N. A história de eco e Narciso. In: Metamorfoses de Ovídio. Trad. Vera Lúcia Leitão Magyar. São Paulo: Madras, 2003. p. 61-65.

ROSSET, C. O real e seu duplo: ensaio sobre a ilusão. 2.ed. Rio de Janeiro: José Olympio, 2000. 
SILVA, S. S. O fluxo do texto. Revista Língua Portuguesa. São Paulo: Editora segmento, ano II, n. 19, 2007.

SANT'ANNA, A. R. Análise estrutural de romances brasileiros. 2.ed. Petrópolis: Vozes, 1973. 